University of Nebraska - Lincoln

DigitalCommons@University of Nebraska - Lincoln

U.S. Navy Research

U.S. Department of Defense

2010

Persian Gulf response to a wintertime shamal wind event

Prasad G. Thoppil

Stennis Space Center, thoppil@nrlssc.navy.mil

Patrick J. Hogan

Stennis Space Center

Follow this and additional works at: https://digitalcommons.unl.edu/usnavyresearch

Thoppil, Prasad G. and Hogan, Patrick J., "Persian Gulf response to a wintertime shamal wind event" (2010). U.S. Navy Research. 48.

https://digitalcommons.unl.edu/usnavyresearch/48

This Article is brought to you for free and open access by the U.S. Department of Defense at DigitalCommons@University of Nebraska - Lincoln. It has been accepted for inclusion in U.S. Navy Research by an authorized administrator of DigitalCommons@University of Nebraska - Lincoln. 


\title{
Persian Gulf response to a wintertime shamal wind event
}

\author{
Prasad G. Thoppil ${ }^{\text {a,*, }}$, Patrick J. Hogan ${ }^{\mathrm{b}}$ \\ a Technology Solutions Group, QinetiQ North America, Stennis Space Center, MS 39529, USA \\ ${ }^{\mathrm{b}}$ Naval Research Laboratory, Open Ocean Processes and Prediction Section, Stennis Space Center, MS 39529, USA
}

\section{A R T I C L E I N F O}

\section{Article history:}

Received 26 October 2009

Received in revised form

22 February 2010

Accepted 4 March 2010

Available online 12 March 2010

\section{Keywords:}

Persian Gulf

Shamal wind

Heat flux

Circulation

Numerical model

\begin{abstract}
A B S T R A C T
The results from a $\sim 1 \mathrm{~km}$ resolution HYbrid Coordinate Ocean Model (HYCOM), forced by $1 / 2^{\circ}$ Navy Operational Global Atmospheric Prediction System (NOGAPS) atmospheric data, were used in order to study the dynamic response of the Persian Gulf to wintertime shamal forcing. Shamal winds are strong northwesterly winds that occur in the Persian Gulf area behind southeast moving cold fronts. The period from 20 November to 5 December 2004 included a well defined shamal event that lasted 4-5 days. In addition to strong winds $\left(16 \mathrm{~m} \mathrm{~s}^{-1}\right)$ the winter shamal also brought cold dry air $\left(T_{a}=20^{\circ} \mathrm{C}\right.$, $q_{a}=10 \mathrm{~g} \mathrm{~kg}^{-1}$ ) which led to a net heat loss in excess of $1000 \mathrm{~W} \mathrm{~m}^{-2}$ by increasing the latent heat flux. This resulted in SST cooling of up to $10{ }^{\circ} \mathrm{C}$ most notably in the northern and shallower shelf regions. A sensitivity experiment with a constant specific humidity of $q_{a}=15 \mathrm{~g} \mathrm{~kg}^{-1}$ confirmed that about $38 \%$ of net heat loss was due to the air-sea humidity differences. The time integral of SST cooling closely followed the air-sea heat loss, indicating an approximate one-dimensional vertical heat balance. It was found that the shamal induced convective vertical mixing provided a direct mechanism for the erosion of stratification and deepening of the mixed layer by $30 \mathrm{~m}$. The strong wind not only strengthened the circulation in the entire Persian Gulf but also established a northwestward flowing Iranian Coastal Current (ICC, $25-30 \mathrm{~cm} \mathrm{~s}^{-1}$ ) from the Strait of Hormuz to about $52^{\circ} \mathrm{E}$, where it veered offshore. The strongest negative sea level of $25-40 \mathrm{~cm}$ was generated in the northernmost portion of the Gulf while the wind setup against the coast of the United Arab Emirates established a positive sea level of $15-30 \mathrm{~cm}$. The transport through the Strait of Hormuz at $56.2^{\circ} \mathrm{E}$ indicated an enhanced outflow of 0.25 $\mathrm{Sv}\left(\mathrm{Sv} \equiv 10^{6} \mathrm{~m}^{3} \mathrm{~s}^{-1}\right)$ during 24 November followed by an equivalent inflow on the next day.
\end{abstract}

(c) 2010 Elsevier Ltd. All rights reserved.

\section{Introduction}

The Persian Gulf (also known as the Arabian Gulf) is a shallow, semi-enclosed basin with a mean depth of about $35 \mathrm{~m}$ and is connected to the deep ( $>1000 \mathrm{~m}$ ) Gulf of Oman through the narrow Strait of Hormuz. It consists of a shallow and wide shelf along the southern part of the Gulf with a depth less than $50 \mathrm{~m}$, and a deep northern part with a maximum depth of $100 \mathrm{~m}$ separated from the coast by a narrow shelf. The circulation in the Persian Gulf is driven by five types of forcing: wind-stress, surface buoyancy fluxes, freshwater runoff, water exchange through the Strait of Hormuz and tides. The winds in the Persian Gulf are predominantly northwesterly throughout the year. During winter (November-February) the winds are slightly stronger $\left(\sim 5 \mathrm{~m} \mathrm{~s}^{-1}\right)$ than those during the summer (June-September) $\left(\sim 3 \mathrm{~m} \mathrm{~s}^{-1}\right)$. The cold, dry-air emanating from the northwest during winter leads to excessive evaporation which results in the convective formation

\footnotetext{
* Correspondence to: Naval Research Laboratory, Open Ocean Processes and Prediction Section, Stennis Space Center, MS 39529, USA. Tel.: +1 228688 5500; fax: +12286884759.

E-mail address: thoppil@nrlssc.navy.mil (P.G. Thoppil).
}

of the saltier and the denser Persian Gulf Water (PGW). The tidal influence on the circulation in the Persian Gulf is insignificant except in the Strait of Hormuz and along the Iranian coast (Blain, 1998, 2000).

The general circulation of the Persian Gulf is cyclonic, which is bounded by an Iranian Coastal Current (ICC) along the northern side, flowing northwestward from the Strait of Hormuz with speed greater than $10 \mathrm{~cm} \mathrm{~s}^{-1}$ (Hunter, 1983), and a southeastward current in the southern part of the Gulf (Figure 34, Reynolds, 1993). The ICC, which flows against the prevailing northwesterly winds, is primarily driven by the pressure gradient (Chao et al., 1992; Lardner et al., 1993; Blain, 2000; Thoppil and Hogan, submitted for publication). The most important circulation feature is the transformation of ICC into a series of mostly cyclonic eddies during August-September (the Iranian Coastal Eddies, ICE, Thoppil and Hogan, submitted for publication). Baroclinic instability along the ICC appears to be the mechanism behind the production of these eddies.

Circulation and water mass formation in the Persian Gulf have been the subject of several previous modeling studies (Lardner et al., 1993; Chao et al., 1992; Blain, 2000; Sadrinasab and Kämpf, 2004; Kämpf and Sadrinasab, 2006; Azam et al., 2006). Several of these studies used hydrodynamic numerical models or spectral 
models of coarse to moderate horizontal resolutions $(20-5 \mathrm{~km})$, and were driven by monthly mean density or atmospheric forcing. While these models reproduced many characteristics of circulation and water-mass reasonably well, they did not resolve the short-term changes associated with the synoptic weather events. Although the prevailing winds are northwesterly throughout the year, they are occasionally interrupted by the episodic, short-lived, strong synoptic wind events, called the shamal. These events can cause abrupt changes in the circulation and heat-budget for a short period of time as demonstrated in the Adriatic Sea responding to the Bora wind events (Lee et al., 2005). None of the above studies have examined the response of the short-term shamal winds on the circulation and heat-budget in the Gulf.

The goal is to study the dynamic responses of the Persian Gulf to a sudden outbreak of a shamal event with particular emphasis on circulation and heat-budget. The approach is to use results from a $\sim 1 \mathrm{~km}$ horizontal resolution Hybrid Coordinate Ocean Model (HYCOM) of the Persian Gulf. The rest of the paper is organized as follows: Shamal winds are introduced in Section 2. Section 3 describes the model configuration and forcing fields. Responses of surface heat fluxes, sea surface temperatures (SSTs), circulation and sea surface height associated with the shamal event are discussed in Section 4. Finally, Section 5 offers a conclusion of the study.

\section{The shamal wind event}

The shamal (Arabic word for north) wind is a strong northerly or northwesterly wind event that occurs in the Persian Gulf during winter as well as summer (Perrone, 1979). The winter shamal occurs mainly between November and March and is directly associated with mid-latitude disturbances moving from west to east. They are caused by the presence of a large pressure gradient that develops behind a cold front passage. Upper level subsidence and rapidly building high pressure over Saudi Arabia and Iraq reinforces the low-level northwesterly winds. Based on duration, there are two types of winter shamal: those which last 24-36 $\mathrm{h}$ and those which last for a longer period of 3-5 days. During a shamal, winds typically reach $15-20 \mathrm{~m} \mathrm{~s}^{-1}$ near the surface during the daytime. A shamal occurs first in the northwestern part of the Gulf and then spreads southeast behind the advancing cold front. Moderate to strong winds can raise desert surface material and reduce visibility. Shamal wind generated storm surges, coupled with tidal effects can lead to significant changes in the sea level of several meters (El-Sabh and Murty, 1989).
In this study, the period from 20 November to 5 December 2004 was selected because it included a well defined shamal event that lasted 4-5 days (24-29 November). Fig. 1 shows the cross-calibrated, multi-platform (CCMP, Atlas et al., 2009) surface winds illustrating the evolution of shamal event. The CCMP wind is produced by combining all satellite derived wind-speed and vector observations, combined with ship and buoy data and the European Centre for Medium-Range Weather Forecasts (ECMWF) analyses (see Atlas et al., 2009 for details). On 20 November 2004, prior to the shamal event, the winds were northwesterly or southeasterly with wind-speeds under $5 \mathrm{~m} \mathrm{~s}^{-1}$. When the shamal began to blow on 23 November, the wind direction changed from southeasterly to a strong northwesterly and on 24 November $12 \mathrm{Z}$ the wind-speed exceeded $15 \mathrm{~m} \mathrm{~s}^{-1}$. The maximum wind-speed $\left(10-15 \mathrm{~m} \mathrm{~s}^{-1}\right)$ occurred in the alongshore direction away from the coast due to orographic control on either side of the Gulf. The wind effect was confined to the region west of $54^{\circ} \mathrm{E}$ (Fig. 1) with a maximum occurring north of Qatar.

A comparison of time-series of wind-stress $\left(\mathrm{N} \mathrm{m}^{-2}\right)$ and windspeed $\left(\mathrm{m} \mathrm{s}^{-1}\right)$ from the Navy Operational Global Atmospheric Prediction System (NOGAPS) and the CCMP at $51^{\circ} \mathrm{E}, 27^{\circ} \mathrm{N}$ revealed that the winds were accurate in the NOGAPS forcing (Fig. 2). The frequent changes in the wind direction were in good agreement with the CCMP. This suggests that the model responses to shamal winds are realistic and thereby provided confidence in our model results. The shamal winds started blowing on 23 November $18 \mathrm{Z}$ $\left(13 \mathrm{~m} \mathrm{~s}^{-1}\right)$, reached peak strength on 24 November $12 \mathrm{Z}$ $\left(16 \mathrm{~m} \mathrm{~s}^{-1}\right)$ and dropped to $2 \mathrm{~m} \mathrm{~s}^{-1}$ on 27 November $00 \mathrm{Z}$. The winds had a southerly component during this brief period. After this short break the wind-speed picked up again and reached $16 \mathrm{~m} \mathrm{~s}^{-1}$ on 28 November $00 \mathrm{Z}$ followed by a gradual weakening.

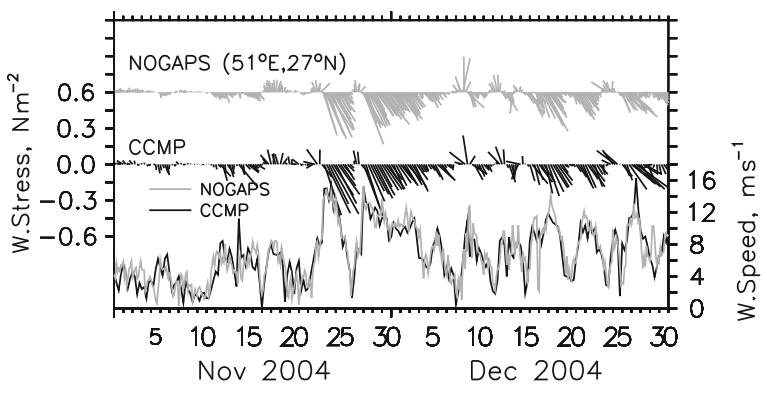

Fig. 2. Comparison of cross-calibrated, multi-platform (CCMP, Atlas et al., 2009) (black) and NOGAPS $0.5^{\circ}$ (grey) wind-stress $\left(\mathrm{N} \mathrm{m}^{-2}\right)$ and wind-speed $\left(\mathrm{m} \mathrm{s}^{-1}\right)$ at $51^{\circ} \mathrm{E}, 27^{\circ} \mathrm{N}$ (Fig. 1a for location). CCMP wind is 6 hourly and NOGAPS is 3 hourly.

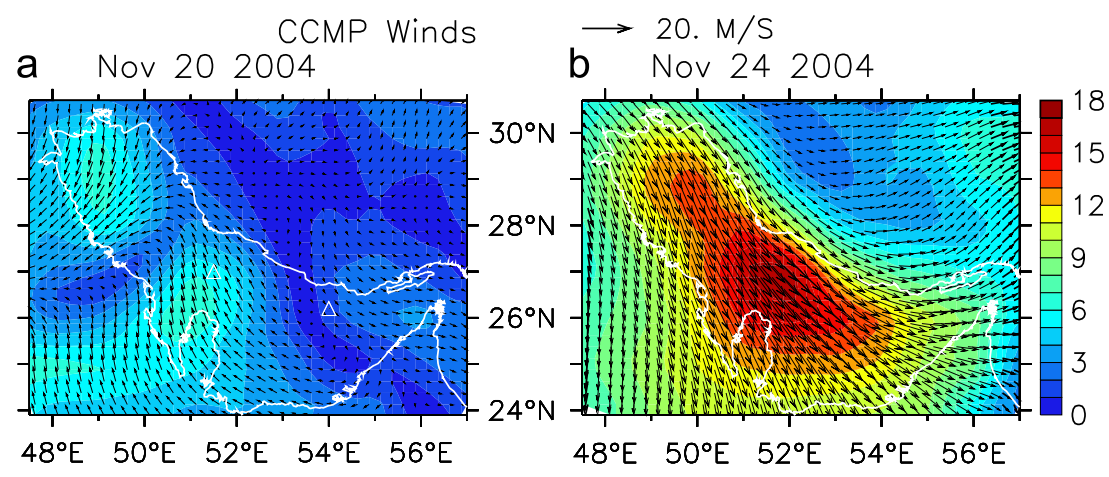

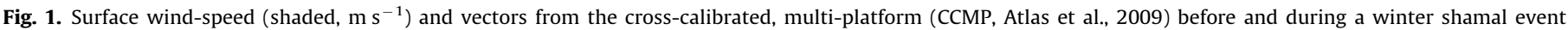
(a) 20 November and (b) $12 Z 24$ November 2004 . 
By 4 December $00 \mathrm{Z}$ its strength decreased to $6 \mathrm{~m} \mathrm{~s}^{-1}$. It should be noted that the CCMP winds are six-hourly and the NOGAPS winds are three-hourly.

\section{Model description}

The HYCOM (Bleck et al., 2002) is used in order to simulate the oceanic responses induced by the shamal winds. Details of the model configuration and forcing fields are described at length by Thoppil and Hogan (2009) and therefore only briefly presented here. The model domain extends northward from $22.3^{\circ} \mathrm{N}$ to $30.7^{\circ} \mathrm{N}$ and eastward from $47.5^{\circ} \mathrm{E}$ to $59.7^{\circ} \mathrm{E}$. The model has 16 hybrid vertical layers and horizontal resolution of $\sim 1 \mathrm{~km}$. The baroclinic (barotropic) time-step is $60 \mathrm{~s}$ (3 s). The eastern boundary is closed $\left(59.7^{\circ} \mathrm{E}\right)$ and outfitted with a 50 grid point buffer zone $\left(\sim 0.5^{\circ}\right)$ in which temperature, salinity and pressure are linearly relaxed toward the Generalized Digital Environmental Model version 3.0 (GDEM3) seasonally varying climatological values (Newtonian damping) with an e-folding time-scale of 1-76 days. The monthly river inflow into the basin is represented as bogused surface precipitation. The model treats rivers as a runoff addition to the surface precipitation field, which acts as a freshwater surface flux that in turn decreases the salinity of the top layer. The monthly mean river discharge values are specified at the river mouths (nearest grid cells). Sea surface salinity was restored to the GDEM3 monthly climatology with a time-scale of $\sim 30$ days. The simulations utilized the GISS (NASA Goddard Institute for Space Studies level 2) vertical mixing scheme, which is constructed using the Reynolds stress model (Canuto et al., 2001, 2002).

The model integration was started from rest on January 1 , 2000 using GDEM3 temperature and salinity and integrated for six years for the period 2000-2005 using $1^{\circ}$, three-hourly NOGAPS forcing. The surface forcing includes wind speed, vector windstress, air temperature, humidity, precipitation, surface shortwave (daily mean) and long-wave heat fluxes. Surface latent and sensible heat fluxes, along with evaporation are calculated using bulk formulae (Kara et al., 2002) during the model run time using model SST. The model reached a steady seasonal cycle during this period. Furthermore, the model integration is continued for another five years (2003-2007) using three-hourly, $1 / 2^{\circ}$ NOGAPS forcing (which is available only after 2003) in which the winds were corrected for the land-sea contamination (Kara et al., 2007) and wind-speed is corrected using the QuikScat winds. The results presented here are from the latter run using $1 / 2^{\circ}$ NOGAPS forcing unless otherwise indicated. The model output is saved as daily snapshots at $00 \mathrm{Z}$, from which monthly averages are prepared. The sampling once per day is not likely to cause major bias on the mean heat flux because the day-night heat flux differences are small due to daily mean solar radiation being used (no diurnal cycle). The results presented here are from the year 2004, particularly during the November-December 2004 period.

\section{Results}

\subsection{Seasonal cycles of SST and heat flux during 2004}

Fig. 3 shows the seasonal cycle of model SST and heat flux during 2004 and comparisons with the Moderate Resolution Imaging Spectroradiometer (MODIS) SST and heat flux based on the objectively analyzed air-sea fluxes (OAFlux, Yu and Weller, 2007). The agreement between the model and MODIS SSTs are very good (correlation $=0.99$ ) with model SSTs being cooler by 1-2 ${ }^{\circ} \mathrm{C}$ during winter. The seasonal cycle in the SST undergoes

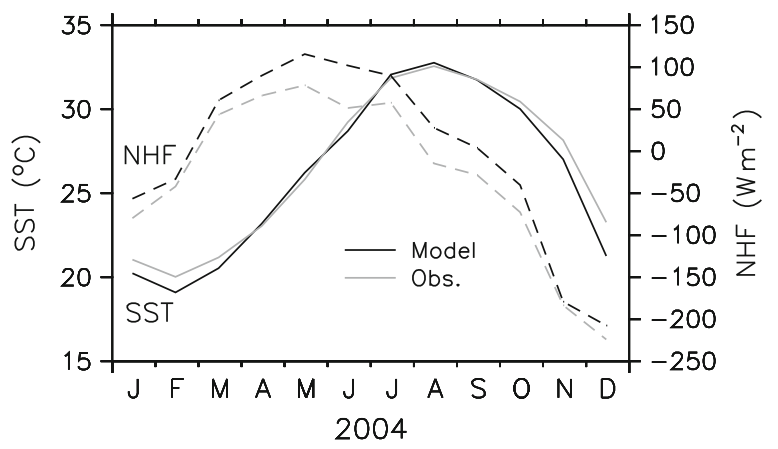

Fig. 3. Seasonal cycle of monthly mean SST $\left({ }^{\circ} \mathrm{C}\right)$ from model (solid dark line) and MODIS (solid grey line) and net surface heat flux $\left(\mathrm{W} \mathrm{m}^{-2}\right)$ from model (dashed dark line) and OAFlux (dashed grey line) (Yu and Weller, 2007) in the Persian Gulf region (west of $56^{\circ} \mathrm{E}$ ) during 2004 . The basin averaged annual mean heat flux from the model (OAFlux) is $-2.3 \mathrm{~W} \mathrm{~m}^{-2}\left(-29 \mathrm{~W} \mathrm{~m}^{-2}\right)$.

cooling during winter $\left(20^{\circ} \mathrm{C}\right)$ and warming in summer $\left(32.5^{\circ} \mathrm{C}\right)$ following the annual cycle of the net surface heat flux (NHF). Winter cooling peaks in February which is two months after the maximum surface heat loss of $200 \mathrm{~W} \mathrm{~m}^{-2}\left(145 \mathrm{~W} \mathrm{~m}^{-2}\right)$ occurred in the model (OAFlux) in December. The reduction in solar radiation together with large latent heat loss (evaporation) driven by the dry-air emanating from the northwest results in surface heat loss. The resulting convective vertical mixing decreases the SST below $\sim 20^{\circ} \mathrm{C}$ in the Gulf and drives a deep mixed layer reaching the bottom (not shown). During summer (May-August), the upper-ocean gains heat mainly due to increased solar radiation concomitant with reduced latent-heat loss owing to weaker winds. The upper-ocean during May-June gains heat by $108 \mathrm{~W} \mathrm{~m}^{-2}$ which is higher than the OAFlux of $74 \mathrm{~W} \mathrm{~m}^{-2}$. The strong near-surface stratification and weak wind-driven mixing during the summer produce a thin mixed-layer $(\sim 10 \mathrm{~m}$, not shown) and warm SSTs.

It is clear that there is a discrepancy between the NHF derived from the OAFlux fields and that obtained from the model (Fig. 3), especially in summer. Despite this differences, SSTs during this period show very good agreement. The basin-averaged (west of $56^{\circ} \mathrm{E}$ ) annual mean NHF from the model is $-2.3 \mathrm{~W} \mathrm{~m}^{-2}$. This value is closer to the basin-averaged net-heat loss of $-7 \pm 4 \mathrm{~W} \mathrm{~m}^{-2}$ obtained from the estimates of advective heat fluxes through the Strait of Hormuz by Johns et al. (2003) and the adjusted Southampton Oceanography Centre climatology (SOC) annual mean value of $4 \mathrm{~W} \mathrm{~m}^{-2}$ (see Johns et al., 2003 for details). However, the basinaveraged annual mean NHF from the OAFlux is $-29 \mathrm{~W} \mathrm{~m}^{-2}$ which lies outside the margin of error. Caution is advised when interpreting the model-data differences because, in the OAFlux, there are only about $26,1^{\circ} \times 1^{\circ}$ grid points in the region west of $56^{\circ} \mathrm{E}$.

\subsection{SST and heat-fluxes during a shamal event}

Time-series of the basin averaged (west of $56^{\circ} \mathrm{E}$ ) NHF, latent and sensible heat fluxes from the OAFlux during a shamal event (November-December, 2004) are depicted in Fig. 4. Pre-storm NHF indicated a net loss of $90 \mathrm{~W} \mathrm{~m}^{-2}$ heat by the ocean on November 22. During the shamal event, the Persian Gulf experienced strong surface heat loss of $474 \mathrm{~W} \mathrm{~m}^{-2}$. As expected, latent heat dominated the total heat loss and contribution from the sensible heat flux was minimal (Fig. 4a). In order to understand the factors contributing to the total heat flux, we examined OAFlux air-sea temperature differences $\left(T_{s}-T_{a}\right)$ and specific humidity of the air $\left(q_{a}, \mathrm{~g} \mathrm{~kg}^{-1}\right)$ (Fig. 4b). The northwesterly winds brought cold dry air into the Persian Gulf 


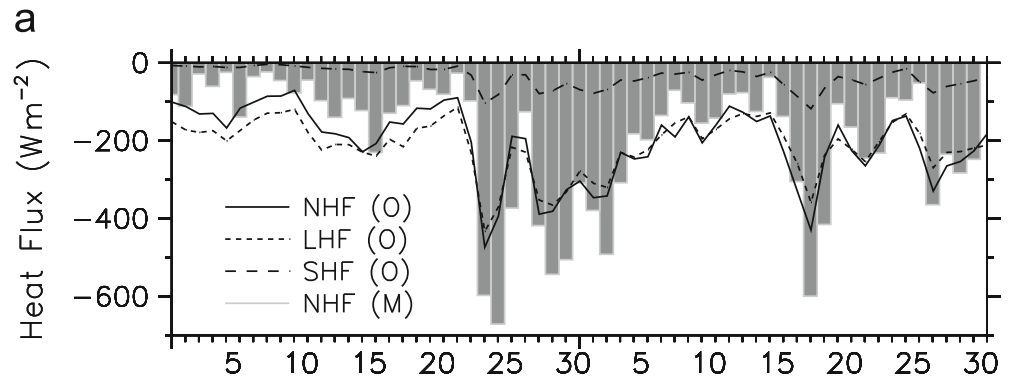

b

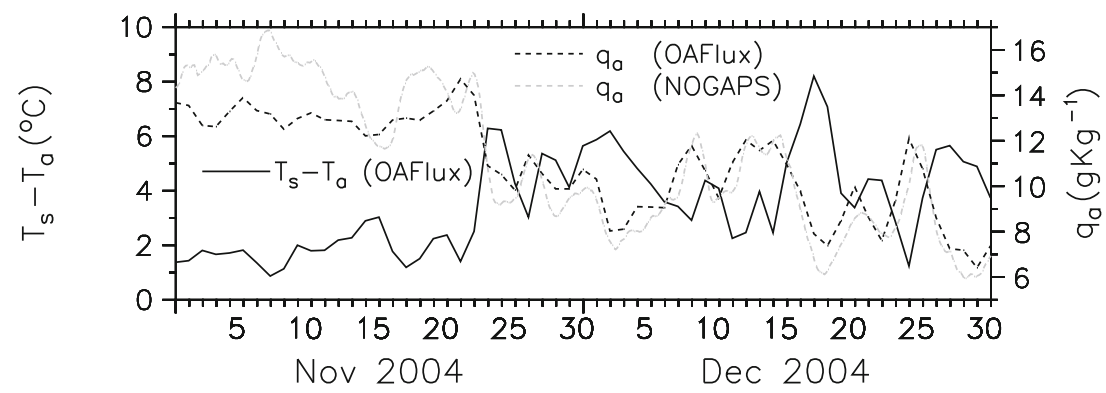

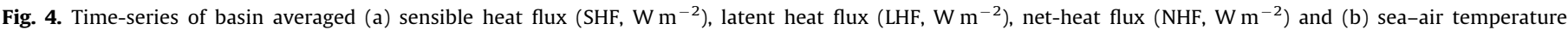

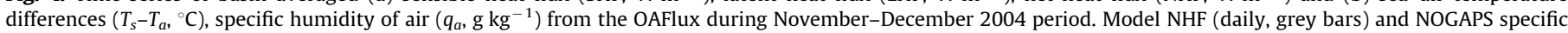
humidity ( 3 hourly, grey line) are included for comparisons. Note that the OAFlux is a daily mean while the model NHF is a daily snapshot at 00Z.

region. As a result, the specific humidity decreased from $14.7 \mathrm{~g} \mathrm{~kg}^{-1}$ on 22 November to $9.8 \mathrm{~g} \mathrm{~kg}^{-1}$ on 25 November. This sharp drop in the humidity combined with strong winds $\left(16 \mathrm{~m} \mathrm{~s}^{-1}\right)$ enhanced the latent heat loss $\left(-433 \mathrm{~W} \mathrm{~m}^{-2}\right.$ on 24 November). A comparison of specific humidity derived from the OAFlux with that derived from the $1 / 2^{\circ}$ NOGAPS revealed good agreement in particular a rapid drop in the humidity associated with the shamal. The air temperature also dropped sharply from $26.3^{\circ} \mathrm{C}$ on 22 November to $20.7{ }^{\circ} \mathrm{C}$ on 24 November resulting in $6.3^{\circ} \mathrm{C}$ sea-air temperature difference. This led to an increase in the sensible heat flux of $104 \mathrm{~W} \mathrm{~m}^{-2}$ during the storm (24 November). Thus, the cold dry air emanating from the northwest enhanced the latent heat loss which led to a net surface heat loss. A perturbation experiment with a constant $q_{a}=15 \mathrm{~g} \mathrm{~kg}^{-1}$ reaffirmed the important role played by this forcing parameter on the total heat loss (Section 4.6).

The surface heat flux from the model shown in Fig. 4a (grey boxes) qualitatively agreed with the OAFlux (solid line). The model NHF was larger than the observations especially during the shamal. Part of the difference stemmed from the fact that the model NHF is a snapshot at $00 \mathrm{Z}$ while OAFlux values are daily averages. In response to the strong wind the heat loss increased from the pre-storm value of $-27 \mathrm{~W} \mathrm{~m}^{-2}$ (22 November) to a maximum value of $-671 \mathrm{~W} \mathrm{~m}^{-2}$ during 25 November. Both the model and observations exhibited a second peak of heat flux on 29 November coinciding with a period of increased wind-speed (Fig. 2). There was yet another period of enhanced heat loss which occurred around 17 December, dominated by latent heat loss, however, this event was not the focus of this study. Following the passage of the shamal winds the heat loss gradually decreased to a near pre-storm condition. The mean heat flux error between the model and the observation during 23-29 November was $-95 \mathrm{~W} \mathrm{~m}^{-2}$.

The surface heat loss resulting from the shamal winds caused SST cooling. Figs. 5a and b contrast the MODIS SST $(1 \mathrm{~km})$ a few days before (17 November) and after (29 November) the shamal event (earliest near cloud-free images available) and their differences (Fig. 5c) quantified the SST cooling. The SSTs prior to the event were warmer than $\sim 28{ }^{\circ} \mathrm{C}$ over most of the region.
The shamal event caused significant SST cooling most notably in the northwestern and shallower shelf regions. The SST over the shelf was noticeably colder by up to $6-8{ }^{\circ} \mathrm{C}$ due to wind-driven mixing and shallower water depth. The cool dry air emanated from the land enhanced SST cooling below $17{ }^{\circ} \mathrm{C}$ in the northernmost portion of the Gulf through stronger latent heat release. SST cooling of $2-4{ }^{\circ} \mathrm{C}$ was noted in the northwestern Gulf where SST dropped below $25^{\circ} \mathrm{C}$. Overall, the response of the SST to the shamal wind was stronger in the northwestern Gulf and was weaker east of $52^{\circ} \mathrm{E}$ despite strong winds.

The model reproduced the observed SST cooling reasonably well. Model SST difference between 29 and 17 November depicted in Fig. 6a were in accordance with the MODIS SST difference (Fig. 5c). Maximum SST cooling of $6-8{ }^{\circ} \mathrm{C}$ occurred over the shelf with magnitude decreasing offshore $\left(-4\right.$ to $\left.-2{ }^{\circ} \mathrm{C}\right)$. The SST near the coast was colder by up to $10^{\circ} \mathrm{C}$, which could not be confirmed in the MODIS due to cloud cover. Again, the northwestern Gulf experienced a stronger cooling $\left(2-4^{\circ} \mathrm{C}\right)$ than the southeast $\left(1-2{ }^{\circ} \mathrm{C}\right)$. This differential SST cooling between the northwestern and southeastern portions of the Gulf can be explained in terms of contrasting net-heat flux (Fig. 6b). The northwestern region experienced a maximum heat loss of $1400 \mathrm{~W} \mathrm{~m}^{-2}$ while the southeast saw only a $400 \mathrm{~W} \mathrm{~m}^{-2}$ heat loss. This northwest and southeast contrast in heat flux can be attributed to the gradient in specific humidity. The humidity varied from $8 \mathrm{~g} \mathrm{~kg}^{-1}$ in the northwest to $13 \mathrm{~g} \mathrm{~kg}^{-1}$ in the southeast indicating drier air and hence larger latent heat loss in the northwest.

To quantify the atmospheric forcing that led to the SST cooling, temperature tendency term $\left(\partial T / \partial t\right.$ in $\left.\mathrm{W} \mathrm{m}^{-2}\right)$ and total heat flux at a location $51^{\circ} \mathrm{E}, 27^{\circ} \mathrm{N}$ are presented in Fig. 7a. As expected, SST changes were caused in large part by the surface heat flux. The upper-ocean experienced a net heat loss in excess of $1000 \mathrm{~W} \mathrm{~m}^{-2}$ which contributed to the abrupt SST cooling. The net heat loss and cool SST drove a deep mixed-layer of $25 \mathrm{~m}$ (mixed-layer increased from 36 to $61 \mathrm{~m}$ ) due to convective vertical mixing. Note that the mixed-layer reached bottom (30 November) following the passage of the storm. The study demonstrated that the heat budget balance during a shamal event is between the surface heat loss and the temperature tendency term. The basin averaged 
a
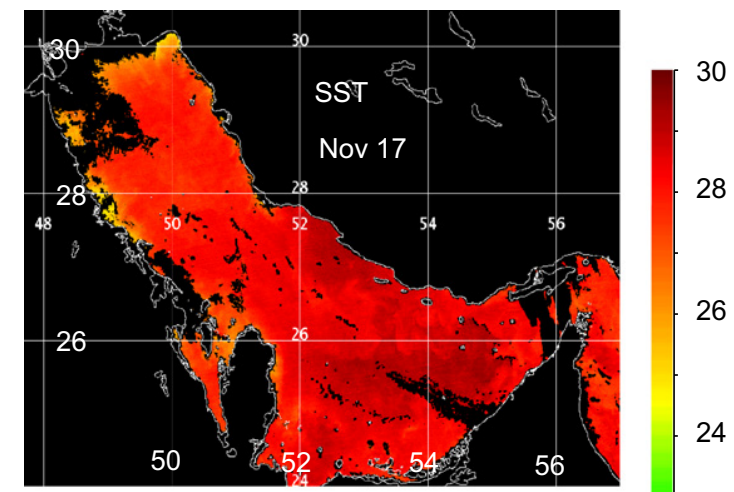

b

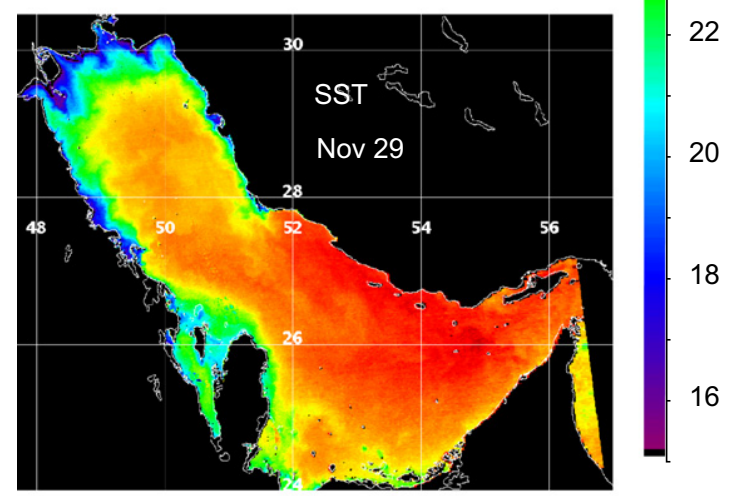

C

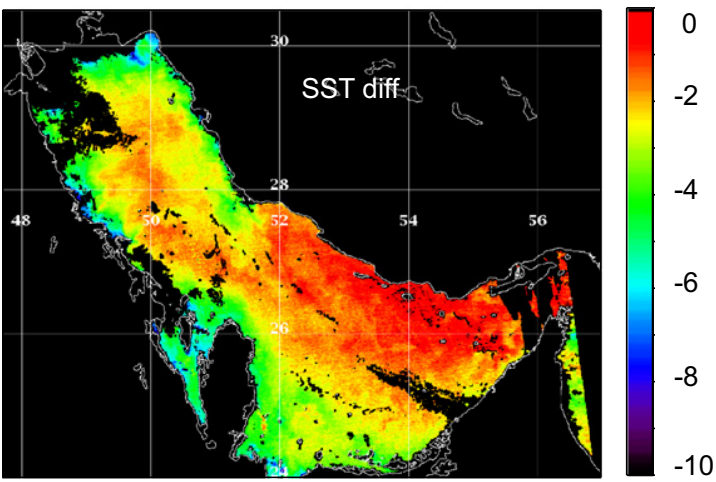

Fig. 5. MODIS (1 km) derived maps of SST during (a) 17 November (b) 29 November 2004 and (c) SST differences $\left(\Delta S S T=S S T_{\text {nov } 29}-S S T_{\text {nov17 }}\right)$ depicting the SST contrasts before and after the shamal event. Black areas indicated the cloud where data were not available. The SST over the shelf was noticeably colder by up to $6-8{ }^{\circ} \mathrm{C}$.

(west of $56^{\circ} \mathrm{E}$ ) contribution of net heat flux to the SST changes over time (time integral) is shown in Fig. $7 \mathrm{~b}$ in terms of the equivalent cooling in ${ }^{\circ} \mathrm{C}$. This emphasizes that the water column cooled rapidly from the air-sea heat loss associated with the shamal. The cumulative SST changes between 20 and 30 November were $-3.6{ }^{\circ} \mathrm{C}$. The SST cooling closely followed the surface heat loss, suggesting that the advective and diffusive processes were negligibly small.

\subsection{Vertical stratification}

The shamal winds not only generated SST cooling but also caused the erosion of thermocline. Vertical profiles of temperature and salinity at two locations in the Gulf $\left(54^{\circ} \mathrm{E}, 26.2^{\circ} \mathrm{N}\right.$ and $\left.51^{\circ} \mathrm{E}, 27^{\circ} \mathrm{N}\right)$, for three days $(20,27$ November and 5 December), shown in Fig. 8 illustrate this. Before the shamal event, the water column was strongly stratified at both locations with a well defined mixed layer depth of $30 \mathrm{~m}$. After the event, the thermocline at the northwestern location $\left(51^{\circ} \mathrm{E}, 27^{\circ} \mathrm{N}\right.$, Fig. $\left.8 \mathrm{~b}\right)$ eroded and the entire water column mixed down to the bottom $(60 \mathrm{~m}$ ) by 5 December. Between 20 November and 5 December, the mixed-layer temperature decreased by $3.5^{\circ} \mathrm{C}$. Similarly the salinity stratification also underwent changes associated with the shamal winds. The pre-storm salinity increased with depth The mixed-layer salinity increased from the pre-shamal event by $\sim 0.15 \%$ due to enhanced evaporation induced by the shamal winds. Contrarily, the shamal had a lesser impact on the stratification at the southeast location $\left(54^{\circ} \mathrm{E}, 26.2^{\circ} \mathrm{N}\right.$, Fig. 8a) where surface heat loss was weaker $\left(-200 \mathrm{~W} \mathrm{~m}^{-2}\right.$, Fig. 6b). The mixed-layer deepened and cooled by $2{ }^{\circ} \mathrm{C}$. The stratification remained stable with salinity increasing with depth. Thus, the shamal event during 24 November accelerated winter cooling and convective mixing due to surface heat loss driven by strong winds and cold dry air emanated from the northwest.

\subsection{Circulation and Eddies}

One of the important features of circulation in the Persian Gulf is the boundary intensified northwestward flowing Iranian Coastal Current (ICC) which is an alongshore flow in geostrophic equilibrium. Between April and July, the ICC becomes progressively stronger and penetrates far into the northern Gulf due to strengthening stratification, increasing inflow and weakening winds. The ICC evolves into a series of mostly cyclonic eddies between July and August. A total of three to five eddies exist and their presence dominate the circulation during the AugustSeptember period (Thoppil and Hogan, submitted for publication). Because of the narrow, shallow and irregular nature of bathymetry, these eddies remain stationary or trapped by the bottom topography until they dissipate locally. They have clear signatures in the surface currents until November, when winter cooling causes the erosion of stratification and the collapse of eddies. The year 2004 was not an exception; the remnants of eddies could be seen prior to the shamal. Fig. 9 shows the MODIS $(1 \mathrm{~km})$ SST, chlorophyll concentration $\left(\mathrm{mg} \mathrm{m}^{-3}\right.$ ) and the model mixed-layer currents during 10 November 2004. The model currents indicated two cyclonic eddies $\left(52.7^{\circ} \mathrm{E}, 26.8^{\circ} \mathrm{N} ; 54.2^{\circ} \mathrm{E}, 26.1^{\circ} \mathrm{N}\right)$ and an anticyclonic eddy $\left(53.5^{\circ} \mathrm{E}, 26.2^{\circ} \mathrm{N}\right)$ sandwiched between them with their diameters ranging from $\sim 50$ to $100 \mathrm{~km}$. The model also shows a string of small cyclonic and anticyclonic eddies traveling from the Strait of Hormuz into the Persian Gulf. The signature of two cyclonic eddies can be delineated from the images of MODIS SST and chlorophyll observations while smaller eddies were difficult to detect.

The strong winds associated with the shamal event had a prominent signature in the current field. The mixed-layer currents prior to the shamal event (20 November) resembled those during 10 November (Fig. 10) in that the remnants of cyclonic eddies (from September 2004) were the dominant circulation features. There was no indication of a northwestward flowing ICC at this time. As expected the strong shamal winds intensified the circulation in the entire Gulf, while the overall responses were different in the northern and southern (alongshore direction) portions of the Gulf. The shamal established an ICC with a distinct maximum offshore speed $\left(25 \mathrm{~cm} \mathrm{~s}^{-1}\right)$, from the Strait of Hormuz to about $52^{\circ} \mathrm{E}$, where it veered offshore. While ICC is a persistent feature between April and July (Thoppil and Hogan, submitted for publication) its reappearance during the shamal was indeed interesting. We also note the strengthening of the southeastward current along the southern portion from Saudi Arabia to the United Arab Emirates, obviously driven by shamal winds. A partial 


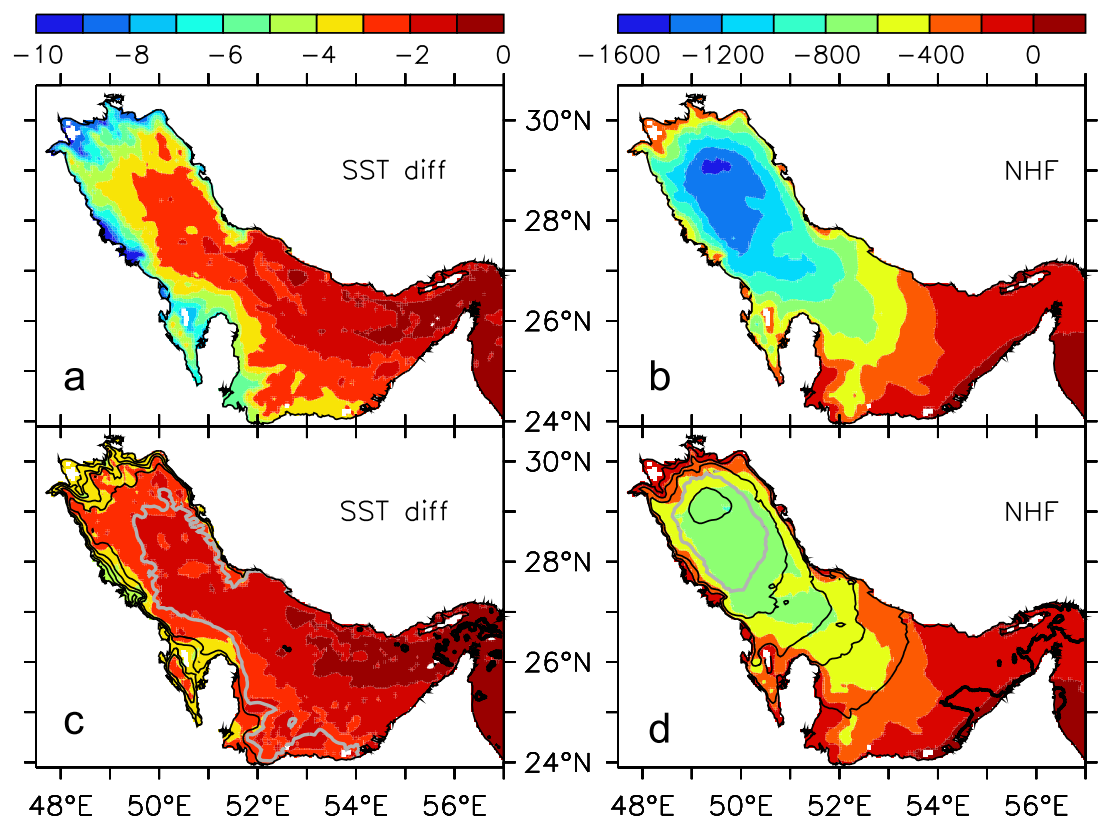

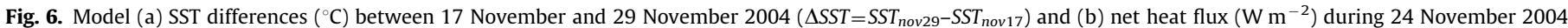

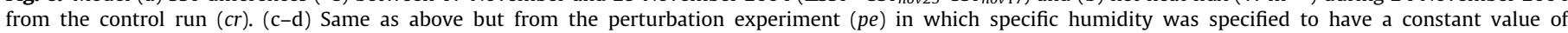

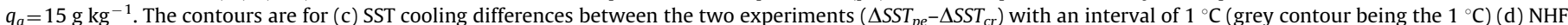

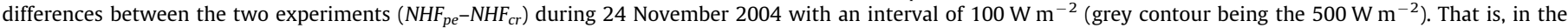
constant humidity run, SST cooling was reduced by $1{ }^{\circ} \mathrm{C}$ and net heat loss was reduced by $500 \mathrm{~W} \mathrm{~m} \mathrm{~m}^{-2}$ from the control run.

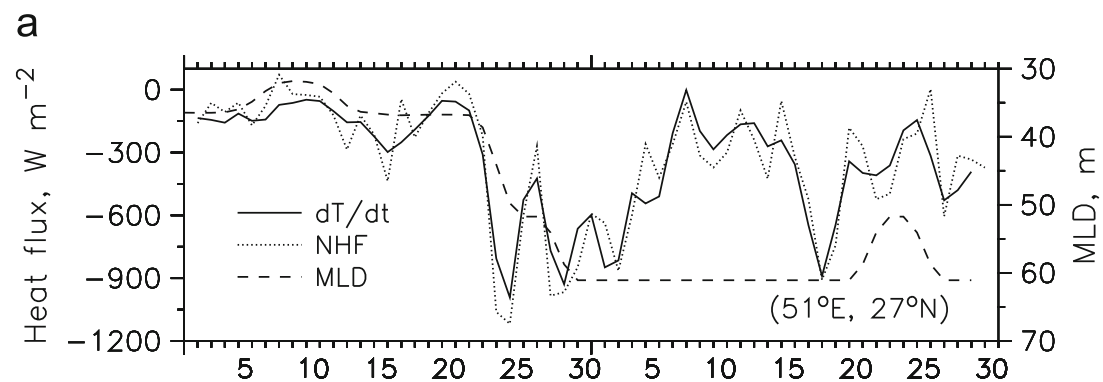

b

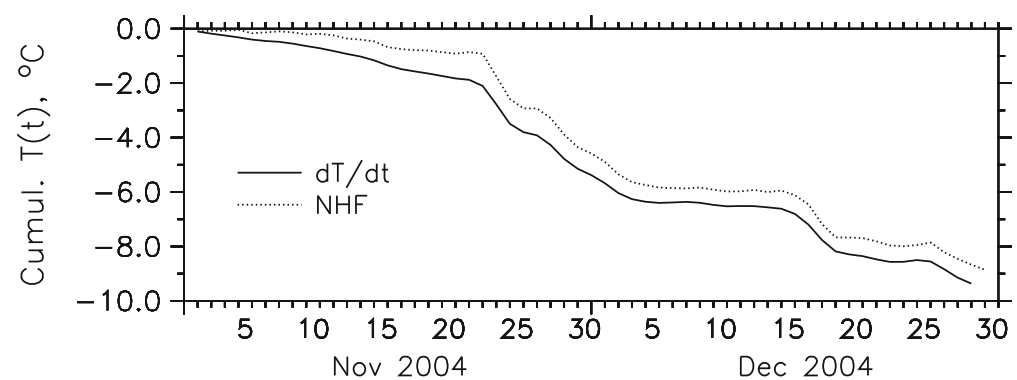

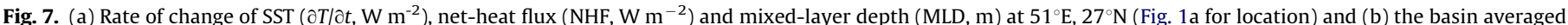
(west of $56^{\circ} \mathrm{E}$ ) time integral (cumulative) of SST change and net-heat flux expressed in ${ }^{\circ} \mathrm{C}$. The SST cooling closely followed the air-sea heat loss.

relaxation of winds on 26 November (Fig. 2) caused the currents to return to a near pre-storm condition on 27 November. The winds continued forcing a persistent ICC until 6 December. On 5 December the ICC and a returning flow to the south constituted a closed cyclonic circulation cell between $52^{\circ} \mathrm{E}$ and $54^{\circ} \mathrm{E}$ and this cell broke down into smaller eddies during 7 December (Fig. 10). Summarizing the shamal response, currents along the southern portions (alongshore direction) of the Gulf were directly winddriven while the currents along the northern portions were the indirect result of the shamal winds through a lagged response to the sea surface height ( $\mathrm{SSH}$ ) difference.

\subsection{Sea surface height and transport}

We now examine the basin wide barotropic response to the strong winds. The simulated SSH before and after the shamal event is depicted in Figs. 11a and b. As a consequence of the wind the SSH minimum occurred in the northernmost part of the Gulf where SSH dropped below $20-30 \mathrm{~cm}$. On the other hand, $\mathrm{SSH}$ increased by $10-20 \mathrm{~cm}$ in the eastern half of the basin. The strongest SSH slope appeared in the northernmost and southern shallow regions. In the latter case, the water piled up along the coast in the southern shallow regions by a strong wind formed a 
a

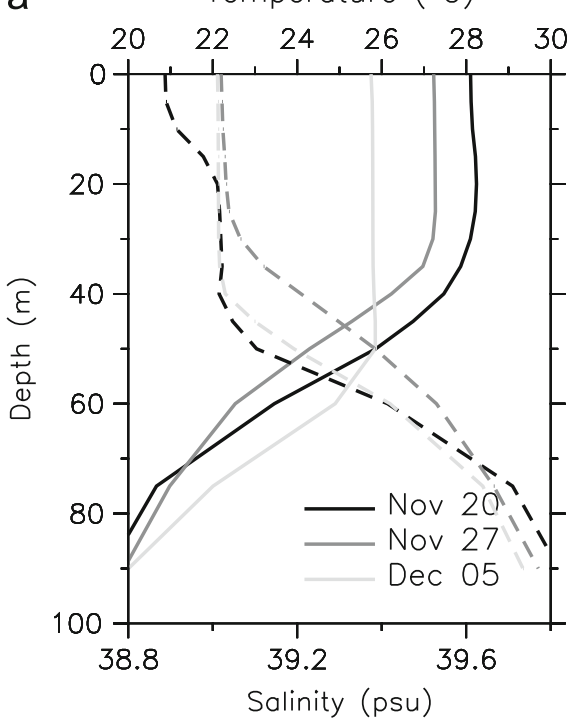

b Temperature $\left({ }^{\circ} \mathrm{C}\right)$

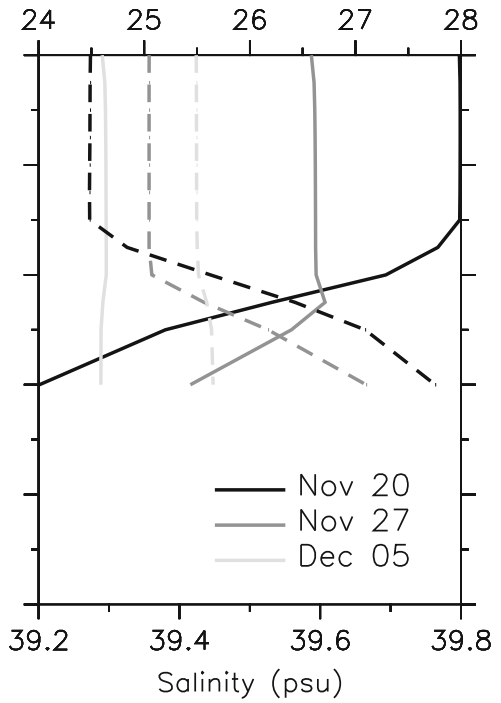

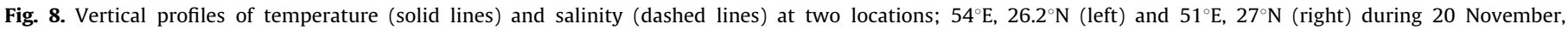
27 November and 5 December 2004. See Fig. 1a for locations.
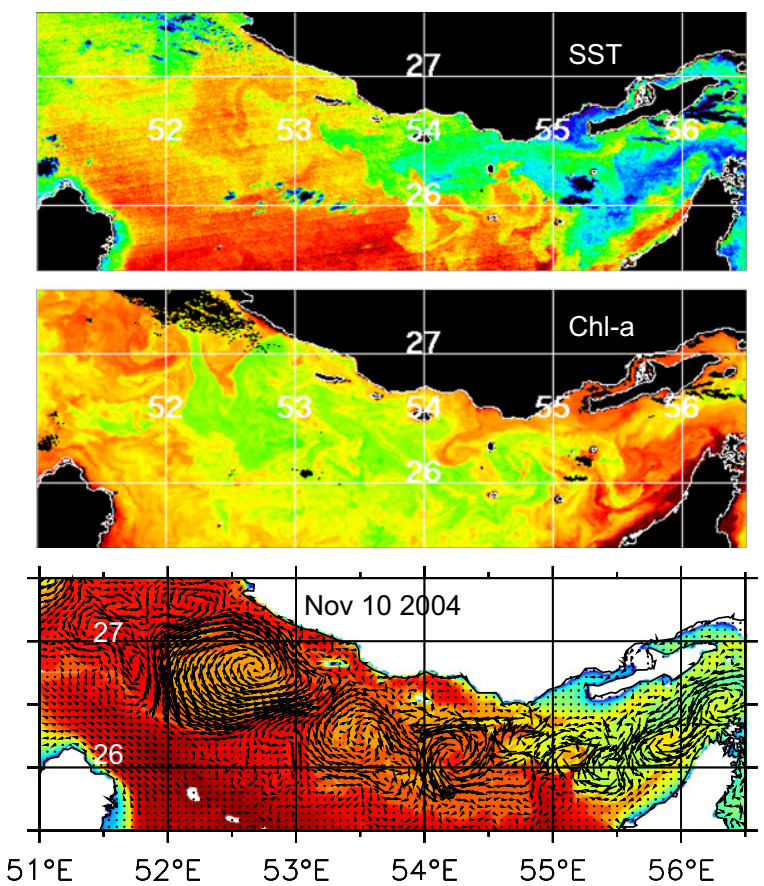

Fig. 9. MODIS $(1 \mathrm{~km})$ derived SST $\left({ }^{\circ} \mathrm{C}\right)$, chlorophyll concentration $\left(\mathrm{mg} \mathrm{m}^{-3}\right)$ and model surface currents overlain on the model SST during 10 November 2004. Ocean color provides a better depiction of eddies and their location compared well with that in the model. It suffices to mention that green represents lower concentrations and yellow and red higher concentrations, since we are not concerned with the magnitude of the chlorophyll concentrations.

high sea surface of $20-30 \mathrm{~cm}$. The SSH pattern simulated by the model qualitatively agreed with a storm surge model responding to an idealized shamal wind structure (El-Sabh and Murty, 1989). They noted positive surges up to $2-3 \mathrm{~m}$ in the shallow southern regions and Bay of Bahrain and negative surges of $1 \mathrm{~m}$ in the northernmost gulf (their Fig. 11), although it should be noted that their model included tidal forcing.

Sea level observation from a coastal station near Bahrain $\left(50.6^{\circ} \mathrm{E}, 26.2^{\circ} \mathrm{N}\right)$ was used to examine the coastal response to the shamal wind. The observed sea level anomaly (SLA, after subtracting the annual mean of 2004) is plotted (grey bars) along with model SSH at $51^{\circ} \mathrm{E}, 27^{\circ} \mathrm{N}$ (solid line) in Fig. 11c. The SLA was positive prior to the storm $(\sim 10 \mathrm{~cm})$. The shamal wind caused a drop of $-16 \mathrm{~cm}$ in SLA on 25 November followed by a rise of $18 \mathrm{~cm}$ in SLA on 27 November. The model SSH at this location failed to simulate the observed sea level pattern. Instead, an examination of $\mathrm{SSH}$ farther north $\left(51^{\circ} \mathrm{E}, 27^{\circ} \mathrm{N}\right)$ revealed a qualitative representation of the observed sea level variability. The fluctuations of the sea level were in phase with the model $\mathrm{SSH}$, an indication that the sea levels were being influenced by changes in wind forcing (Fig. 2). It should be noted that tidal components are also important in determining the total sea level in the Persian Gulf, which has not included in the model.

The sea level difference between the northwestern (west of $\left.52^{\circ} \mathrm{E}\right)$ and southeastern $\left(52^{\circ} \mathrm{E}-56^{\circ} \mathrm{E}\right)$ portions of the Gulf induced by shamal winds can be, in part, responsible for the variability in the ICC. The area averaged SSH difference $\left(\Delta S S H=S S H_{\text {west }}-S_{S H} H_{\text {east }}\right)$ and zonal velocity $(u)$ at $53.1^{\circ} \mathrm{E}, 26.7^{\circ} \mathrm{N}$ within the core of ICC depicted in Fig. 12a showed significant correlation of 0.72 with $u$ leading $\triangle S S H$ by 1 day. It is also reasonable to speculate that the flow variability can arise from the variability in the inflowoutflow exchange through the Strait of Hormuz. The transport through the Strait at $56.2^{\circ} \mathrm{E}$ for the northern (north of $26.4^{\circ} \mathrm{N}$ ) and southern portions (south of $26.4^{\circ} \mathrm{N}$ ) clearly showed variability associated with the shamal (Fig. 12b). The outflow increased to $0.25 \mathrm{~Sv}\left(\mathrm{~Sv} \equiv 10^{6} \mathrm{~m}^{3} \mathrm{~s}^{-1}\right)$ on 24 November followed by an enhanced inflow of $0.25 \mathrm{~Sv}$ during 25 November. Similarly, an accelerated outflow $(0.17 \mathrm{~Sv})$ followed by an inflow $(0.26 \mathrm{~Sv})$ occurred during 28-29 November. These periods of enhanced inflow produced a stronger ICC along the coast of Iran (Fig. 10) implying that they are connected. We speculate that the ICC is a lagged response to the SSH difference, however, a detailed analysis is beyond the scope of this paper.

\subsection{Sensitivity to humidity}

In order to identify and isolate the influence of humidity on the latent heat loss and hence on the net heat loss during a shamal (Figs. 4 and 6b), we carried out a perturbation model experiment 





clarity, velocity vectors whose magnitudes larger than $4 \mathrm{~cm} \mathrm{~s}^{-1}$ are plotted. Every 10 th vector is plotted. Iranian Coastal Current (ICC) is marked.

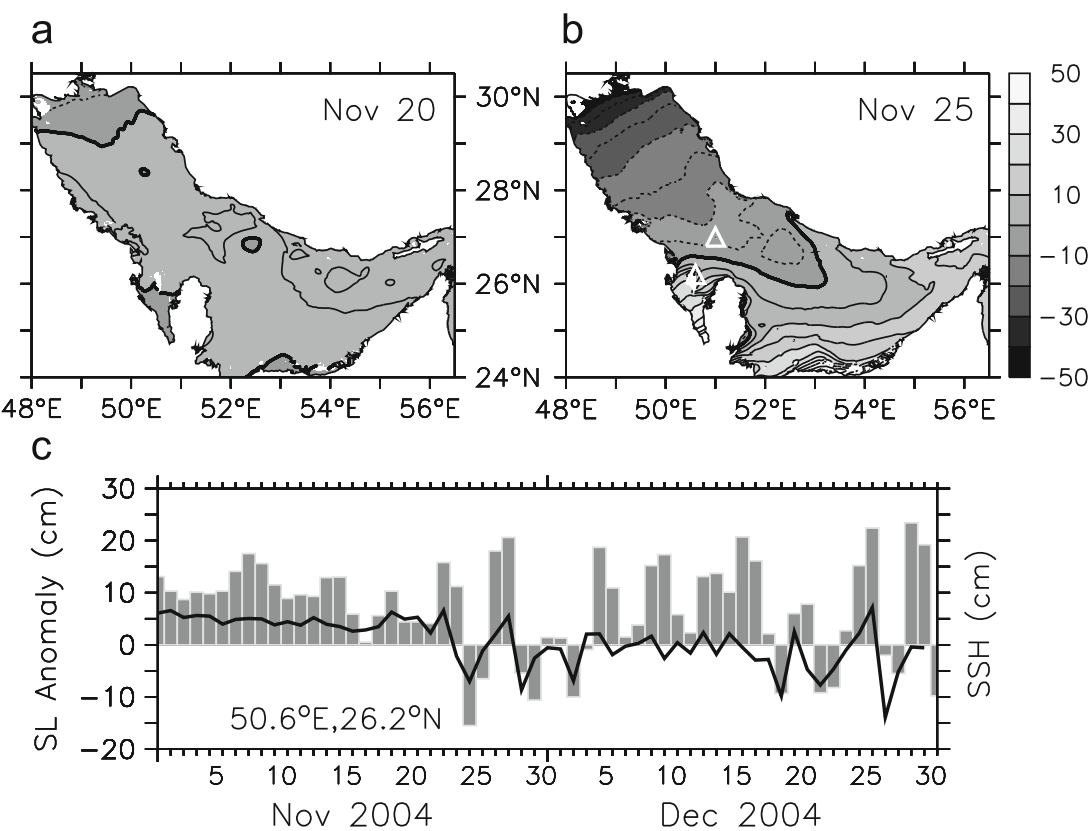

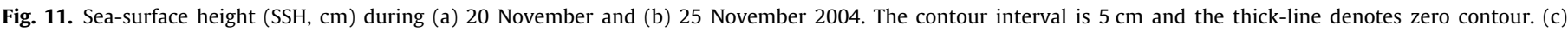

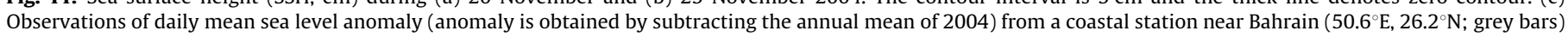
and model $\mathrm{SSH}$ at $51^{\circ} \mathrm{E}, 27^{\circ} \mathrm{N}$ (solid line; see Fig. $11 \mathrm{~b}$ for locations).

by maintaining a constant value of $q_{a}=15 \mathrm{~g} \mathrm{~kg}^{-1}$ specific humidity of air from 1 to 30 November 2004. The choice of this value broadly represented the pre-storm conditions in both OAFlux and the NOGAPS fields (Fig. 4b). The SST differences (29-17 November) and net heat flux (24 November) from this experiment are depicted in Figs. $6 c$ and d. The difference in net heat flux in the constant humidity run was substantial and accounted for a change of $400-500 \mathrm{~W} \mathrm{~m}^{-2}$ from the control run.
The northwestern Gulf experienced a maximum net heat loss of $800 \mathrm{~W} \mathrm{~m}^{-2}$ in contrast to $1400 \mathrm{~W} \mathrm{~m}^{-2}$ in the control run. These differences were primarily due to a reduction in the latent heat flux caused by higher humidity. When averaged over the basin west of $56^{\circ} \mathrm{E}$, the NHF due to humidity alone accounted for $38 \%$ of the total heat loss. The reduction of NHF had a noticeable impact on the SST cooling especially along the coastal regions (Fig. 6c), where SST cooling was weaker than the control run by $2-4{ }^{\circ} \mathrm{C}$. 
a

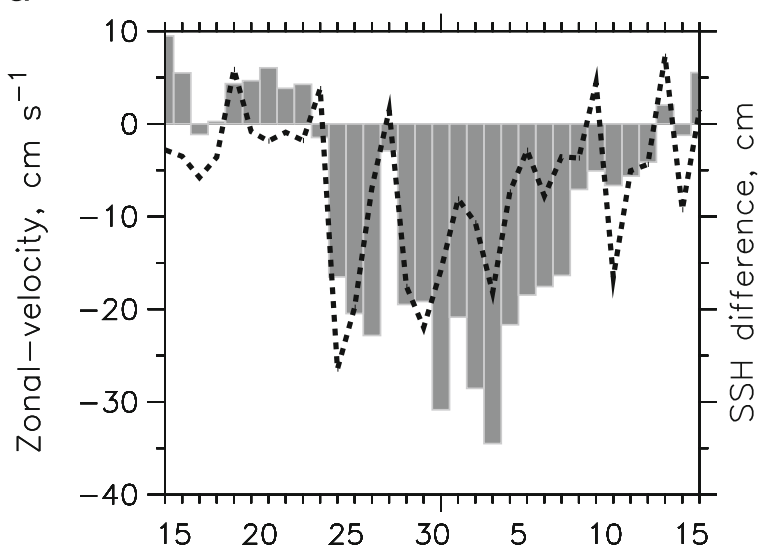

b

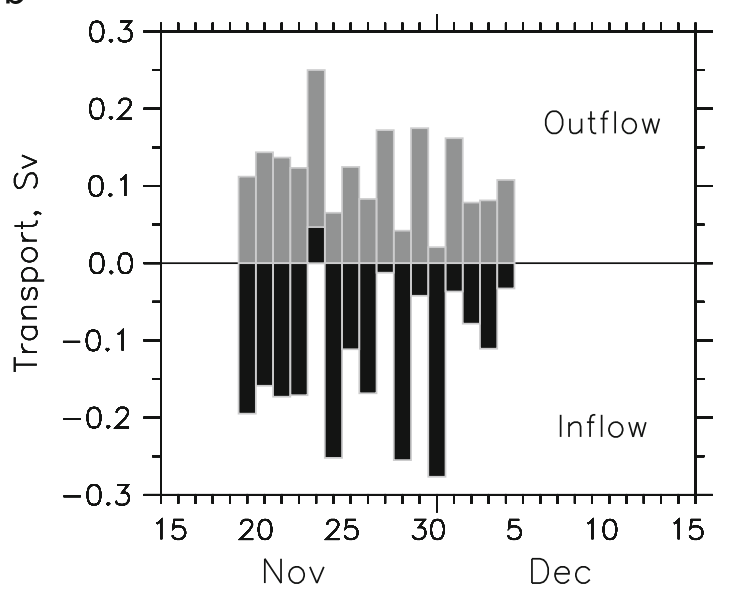

Fig. 12. (a) Sea surface height difference between the northwestern (west of $52^{\circ} \mathrm{E}$ ) and southeastern $\left(52-56^{\circ} \mathrm{E}\right)$ portions of the Persian Gulf (dotted line) and zonal velocity $\left(u, \mathrm{~cm} \mathrm{~s}^{-1}\right)$ within the core of Iranian Coastal Current (ICC) at $53.1^{\circ} \mathrm{E}$, $26.7^{\circ} \mathrm{N}$. Note that SSH difference is plotted with a 1-day lag. (b) Transport (Sv) across the Strait of Hormuz at $56.2^{\circ} \mathrm{E}$ for the northern (north of $26.4^{\circ} \mathrm{N}$; dark bars) and southern portions (south of $26.4^{\circ} \mathrm{N}$; grey bars) of the Strait.

Elsewhere the SST cooling was $0-1{ }^{\circ} \mathrm{C}$ different from the control run. Thus, the sensitivity experiment reiterated the role of humidity in determining the winter cooling and heat-budget in the northern Gulf during a shamal event.

\section{Conclusions}

Results from a high-resolution HYbrid Coordinate Ocean Model (HYCOM), forced by $1 / 2^{\circ}$ NOGAPS atmospheric data, were used in order to study the dynamical response of the Persian Gulf to a winter time shamal forcing. The period of 20 November -5 December 2004 was selected because it included a well defined shamal event that lasted about 4-5 days (24-29 November). In addition to the strong winds $\left(16 \mathrm{~m} \mathrm{~s}^{-1}\right)$, the winter shamal brought cold dry air that lead to enhanced surface heat loss and evaporation. The Persian Gulf experienced strong cooling with surface heat loss in excess of $1000 \mathrm{~W} \mathrm{~m}^{-2}$. This resulted in significant SST cooling most notably in the northern and shallower shelf regions. The SST over the shelf was noticeably colder by up to $10{ }^{\circ} \mathrm{C}$ due to surface heat loss and wind-driven mixing. The heat-budget balance during the shamal event was between the surface heat flux and the temperature tendency term and contributions from the advective/diffusive term appeared negligible. A sensitivity experiment with a constant specific humidity of $q_{a}=15 \mathrm{~g} \mathrm{~kg}^{-1}$ confirmed that about $38 \%$ of net heat loss was due to the air-sea humidity differences. The shamal event also significantly contributed to the erosion of vertical stratification. The pre-shamal vertical temperature at $51^{\circ} \mathrm{E}, 27^{\circ} \mathrm{N}$ indicated a strongly stratified water column with a mixed layer depth of $30 \mathrm{~m}$. After the shamal thermocline eroded and the entire water column mixed down to its bottom (60 m).

The remnants of mesoscale to sub-mesoscale eddies from late summer (August-September 2004) dominated pre-shamal circulation in the Gulf. Perhaps, one of the most intriguing features of the circulation during the shamal was the genesis of a $25 \mathrm{~cm} \mathrm{~s}^{-1}$ northwestward flowing Iranian Coastal Current (ICC) from the Strait of Hormuz to north of Qatar. It veered offshore at about $52^{\circ} \mathrm{E}$ with a branch continuing northwestward and another branch joining the return southeastward flow to the right. The shamal winds also intensified the outflowing branch of the cyclonic circulation; part of it terminated before reaching the Strait. The ICC persisted until 6 December and then collapsed into smaller eddies due to weakening winds and eroding stratification.

The barotropic response of the Gulf to shamal event reasonably agreed with the observations of sea level. The strongest positive sea level slope was generated in the southern shallow regions associated with the wind setup against the United Arab Emirates coast (piling up of water near the coast) while the strongest negative sea level slope was formed in the northernmost part of the Gulf. The area averaged sea surface height (SSH) difference and zonal velocity $(u)$ within the core of ICC showed a significant correlation of 0.72 with $u$ leading SSH by 1-day suggesting that part of the ICC variability was driven by the SSH fluctuations.

We have for the first time presented the dynamic response of the Persian Gulf to a wintertime shamal event using model results and satellite observations with a special emphasis on the surface circulation and heat-budget. The shamal winds in summer will induce a different response because summertime stratification is stronger and has a much stronger inflow of low-salinity water along the coast of Iran. The extent to which the short-lived shamal winds impact the long-term circulation in the Gulf is relatively unknown. The sharp differences in the stratification between summer and winter make the response time differ. Although the prevailing winds are generally northwesterly throughout the year, short episodes of very strong shamal winds can change the surface circulation abruptly during short spells of a few days to weeks. Frequent episodes of shamal winds may lead to an increase in the intensity of the cyclonic circulation by altering the exchange circulation through the Strait of Hormuz. Exclusion of these events in the modeling studies are likely to underestimate the surface circulation. More systematic studies using remotely sensed and in situ data in conjunction with numerical modeling would aid in our understanding of the complex air-sea interaction and circulation that are taking place during shamal events. A prior knowledge of circulation in response to the shamal wind is not only useful for navigation, but is essential to understanding of the movement of oil slicks.

\section{Acknowledgements}

This paper is a contribution to the coastal ocean nesting studies project sponsored by the Office of Naval Research (ONR) under the program element $601153 \mathrm{~N}$. It is also a contribution to the NRL project Full Column Mixing for Numerical Ocean Models. The simulations were performed on IBM-SP4 workstations at the Naval Oceanographic Office under a grant of computer time from the DoD High Performance Computer Modernization Office (HPCMO). Alan Wallcraft is thanked for his substantial contribution to this effort through his work on model development and his 
computer expertise. MODIS data is downloaded from poet.jpl. nasa.gov and oceancolor.gsfc.nasa.gov.

\section{References}

Atlas, R., Hoffman, R.N., Ardizzone, J., Leidner, S.M., Jusem, J.C., 2009. Development of a new cross-calibrated, multi-platform (CCMP) ocean surface wind product. In: The Proceedings of the AMS 13th Conference on Integrated Observing and Assimilation Systems for Atmosphere, Oceans, and Land Surface (IOAS-AOLS).

Azam, M.H., Elshorbagy, W., Ichikawa, T., Terasawa, T., Taguchi, K., 2006. 3D model application to study residual flow in the Arabian Gulf. J. Waterw., Port, Coastal. Ocean Eng. 132 (5), 388-400.

Blain, C.A., 1998. Barotropic and tidal residual circulation in the Arabian Gulf. In: Spaulding, M.L., Blumberg, A.F. (Eds.), Estuarine and Coastal Modeling, Proceedings of the 5th International Conference. American Society of Civil Engineers, pp. 166-180.

Blain, C.A., 2000. Modeling three-dimensional thermohaline-driven circulation in the Arabian Gulf. In: Spaulding, M.L., Lee Butler, H. (Eds.), Proceedings of the 6th International Conference on Estuarine and Coastal Modeling. ASCE, Reston, VA, pp. 74-93.

Bleck, R., Halliwell, G.R., Wallcraft, A.J., Carroll, S., Kelly, K., Rushing, K., 2002. HYbrid Coordinate Ocean Model (HYCOM) User's Manual: Details of the Numerical Code (available from 〈http://hycom.rsmas.miami.edu $\rangle$ ).

Canuto, V.M., Howard, A., Cheng, Y., Dubovikov, M.S., 2001. Ocean turbulence. Part I: one-point closure model. Momentum and heat vertical diffusivities. J. Phys. Oceanogr. 31, 1413-1426.

Canuto, V.M., Howard, A., Cheng, Y., Dubovikov, M.S., 2002. Ocean turbulence. Part II: vertical diffusivities of momentum, heat, salt, mass and passive scalars. J. Phys. Oceanogr. 32, 240-264.

Chao, S.-Y., Kao, T.W., Al-Hajri, K.R., 1992. A numerical investigation of circulation in the Arabian Gulf. J. Geophys. Res. 97, 11219-11236.

El-Sabh, M.I., Murty, T.S., 1989. Storm surges in the Arabian Gulf. Natural Hazards $1,371-385$.
Hunter, J.R., 1983. The physical oceanography of the Arabian Gulf: a review and theoretical interpretation of previous observations. In: Marine Environment and Pollution, Proceedings of the First Arabian Gulf Conference on Environment and Pollution, Kuwait, 7-9 February 1982, pp. 1-23.

Johns, W.E., Yao, F., Olson, D.B., Josey, S.A., Grist, J.P., Smeed, D.A., 2003. Observations of seasonal exchange through the Straits of Hormuz and the inferred freshwater budgets of the Persian Gulf. J. Geophys. Res. 108 (C12), 3391, doi:10.1029/2003JC001881.

Kämpf, J., Sadrinasab, M., 2006. The circulation of the Persian Gulf: a numerical study. Ocean Sci. 2, 1-15.

Kara, A.B., Rochford, P.A., Hurlburt, H.E., 2002. Air-sea flux estimates and the 1997-1998 ENSO event. Boundary-Layer Meteorol. 103, 439-458.

Kara, A.B., Wallcraft, A.J., Hurlburt, H.E., 2007. A correction for land contamination of atmospheric variables near land-sea boundaries. J. Phys. Oceanogr. 37, 803-818.

Lardner, R.W., Al-Rabeh, A.H., Gunay, N., Hossain, H., Reynolds, R.M., Lehr, W.J., 1993. Computation of the residual flow in the Gulf using the Mt. Mitchell data and the KFUPM/RI hydrodynamical models. Mar. Pollut. Bull. 27, $61-70$.

Lee, C.M., et al. (19 authors), 2005. Northern Adriatic response to a wintertime Bora wind event. EOS Trans. AGU 86(16), 10.1029/2005E0160001.

Perrone, T.J., 1979. Winter shamal in the Persian Gulf, Naval Env. Prediction Res. Facility, Technical Report, 79-06, Monterey, 180pp.

Reynolds, R.M., 1993. Physical oceanography of the Gulf, Strait of Hormuz and the Gulf of Oman-results from the Mt. Mitchell expedition. Mar. Pollut. Bull. 27, 35-59.

Sadrinasab, M., Kämpf, J., 2004. Three-dimensional flushing times in the Persian Gulf. Geophys. Res. Lett. 31, L24301, doi:10.1029/2004GL020425.

Thoppil, P.G., Hogan, P.J. A modeling study of circulation and eddies in the Persian Gulf. J. Phys. Oceanogr., submitted for publication.

Thoppil, P.G., Hogan, P.J., 2009. On the mechanisms of episodic salinity outflow events in the Strait of Hormuz. J. Phys. Oceanogr. 39, 1340-1360, doi:10.1175/ 2008JP03941.1.

Yu, L., Weller, R.A., 2007. Objectively analyzed air-sea heat fluxes (OAFlux) for the global oceans. Bull. Am. Meteorol. Soc. 88, 527-539. 